\title{
The LIFE certification methodology as a diagnostic tool of the environmental management system of the automotive industry
}

\author{
Ricardo Reale ${ }^{\mathrm{a}, *}$, Luiz César Ribas ${ }^{\mathrm{b}}$, Regiane Borsato ${ }^{\mathrm{c}}$, Teresa Cristina Magro ${ }^{\mathrm{a}}$, \\ Maureen Voigtlaender ${ }^{\mathrm{a}}$ \\ a Department of Forest Science, ESALQ University of Sao Paulo, Padua Dias Avenue, 11, Piracicaba, SP, CEP: 13418-900, Brazil \\ ${ }^{\mathrm{b}}$ Economics, Sociology and Technology Department, College of Agricultural Sciences of Botucatu, UNESP, Fazenda Lageado, Portaria I: José Barbosa de Barros \\ Street, 1780, Botucatu, SP CEP: 18.610-307, Brazil \\ ' ${ }^{\mathrm{L}}$ LIFE Institute, Victor Benato Street, 210-Unilivre, Pilarzinho, Curitiba, PR CEP: 82120-110, Brazil
}

\section{A R T I C L E I N F O}

\section{Article history:}

Received 22 August 2015

Received in revised form 16 December 2015

Accepted 17 December 2015

Available online 4 January 2016

\section{Keywords:}

Conservation

Biodiversity

Mitigation of impacts

Economy

LIFE certification

Environmental management

\begin{abstract}
A B S T R A C T
We conducted a diagnosis of the environmental management system of the Brazilian auto parts industry, using the LIFE certification methodology (lasting initiative for earth) as a diagnostic tool. This certification recognizes enterprises that develop conservation actions for biodiversity for the purpose of minimizing and/or mitigating their own negative impact on the environment. Through this method, it was possible to quantify and qualify the environmental impact and investigate the existence of conservation actions, as well as evaluate them quantitatively and qualitatively. Therefore, we used this methodology to demonstrate its potential as an economic instrument of environmental management through its application within an EMS certified to the ISO 14001 series. It was shown that there are many benefits of using sustainable environmental resources (possibility to return to ISE-Corporate Sustainability IndexBovespa) and for the final disposal of waste from production. The main results indicated that the LIFE methodology allows companies to incorporate actions to biodiversity conservation transversally into their EMSs, which can increase the efficiency of enterprise management. We believe that the use of this management model by other companies will enable the intensification of conservation actions in protected areas in their regions.
\end{abstract}

(c) 2015 Elsevier Ltd. All rights reserved.

\section{Introduction}

This study evaluated the environmental management system (EMS) of an auto parts industry with the intent to improve the management of the company, demonstrating the importance of biodiversity conservation as a cross tool for the current model of corporate management.

The tool used in this study is the LIFE certification, which inserts the biodiversity theme as main indicator of negative environmental impacts produced by companies and industries. The methodology applies to any company or industry, preferentially that has ISO 14001 certificate. This preference occurs because the EMS is certified to ISO, what attest the political environmental, that is important to the new concepts from LIFE. Thus, this study presents the methodology LIFE certification, applying in a study case in an auto parts industry in Brazil.

\footnotetext{
* Corresponding author.

E-mail address: realericardo@usp.br (R. Reale).
}

According to the Brazilian Panel on Climate Change report, between the pre-industrial period of 1750 and 2014, there was a $40 \%$ increase in atmospheric $\mathrm{CO}_{2}$ levels across the globe (PBMC, 2014). The main reasons for this problem are the great burning of fossil fuels, the rapid expansion of the agricultural frontier and the rapid industrial growth. Additionally, natural areas have been changed and have had their biodiversity reduced dramatically, promoting large and rapid changes in the biogeochemical cycles of the planet, damaging the ecosystem processes (Chapin et al., 2000).

Due to the lack of environmental management from various economic sectors since the Industrial Revolution until the midtwentieth century, various environmental disasters have occurred worldwide. For example, we can cite the "Dust Bowls", i.e., sandstorms that occurred in the Midwest of the United States between 1920 and 1950. Huge losses occurred in all sectors: environmental, economic and social (Tuffani, 2010; Marques, 2000).

Several other catastrophic events have happened around the world throughout the twentieth century, particularly environmental accidents in industries with major environmental, 
economic and social impacts. Thus, the second half of the twentieth century saw increased public pressure for improvements related to environmental issues (Reale, 2014).

The main meetings between countries, after 1950s, started to address new ways to reduce the environmental degradation. Several international agreements were performed to try recuperating degraded areas and turning them in key biodiversity areas until end on the twentieth century (Marques, 2000). Researches economic sciences together with environmental sciences an integrated manner demonstrated that in addition to ecosystem services provide the full range of benefits to the world's population are also extremely important for the global economy (Sukhdev et al., 2010).

Already, 21st Conference of the Parts (COP-21) to the United Nations Convention on Climate Change (UNFCCC), occurred in 2015 , determined that humanity must tackle global warming in the coming decades by limiting the increase in global temperature below 2 degrees Celsius above pre-industrial levels. Thus, diminish risks of climate change impacts on biodiversity.

To meet objectives of COP-21, countries should implement their Intended Nationally Determined Contributions (INDCs). Because that, will be major effort between governments and enterprises for that environmental actions are implemented and targets are being met. LIFE certification is highlighted because its methodology helps organizations to assess their own EMS. At the end of the evaluation, the LIFE methodology also proposes how much the company should develop in actions for biodiversity conservation to mitigate and/or minimize environmental impacts caused by its production processes.
Ecosystem services provide direct benefits, such as water, energy and food, regulatory benefits, such as flood and erosion control and water purification, or indirect benefits, such as nutrient cycling, soil production and photosynthesis (Zolin et al., 2014). Thus, they have great importance for the world economy, as noted by Bulhões (2012), who showed that $40 \%$ of the world economy is based on biodiversity arising from products or their ecological processes.

Although large industries possess environmental certification for EMS and respect the rules and environmental regulations law, the planet still lives under a great wave of environmental degradation and climate change. That occurs because big and small companies yet do a reduced number of actions for the biodiversity conservation. Importantly that simply follow the current legislation is mandatory and the minimum acceptable requirement to decrease a company's environmental impacts. However, frequently many industries begin to worsen after some years of their installation.

The obligation to respect the legislation is an intrinsic factor of all citizens and companies on the planet. Thus, a good EMS is not one that rigidly follows the law applied to an enterprise, but rather one that voluntarily develops interrelated social, economic and environmental actions.

Therefore, we performed an assessment of the environmental management of an industry that has ISO 14001 certification. The purpose is to demonstrate the LIFE Certification methodology as an environmental diagnostic tool for companies. In this way, it is possible to note improvements in an enterprise, encouraging the integration of biodiversity to its management. Thus, the entire EMS

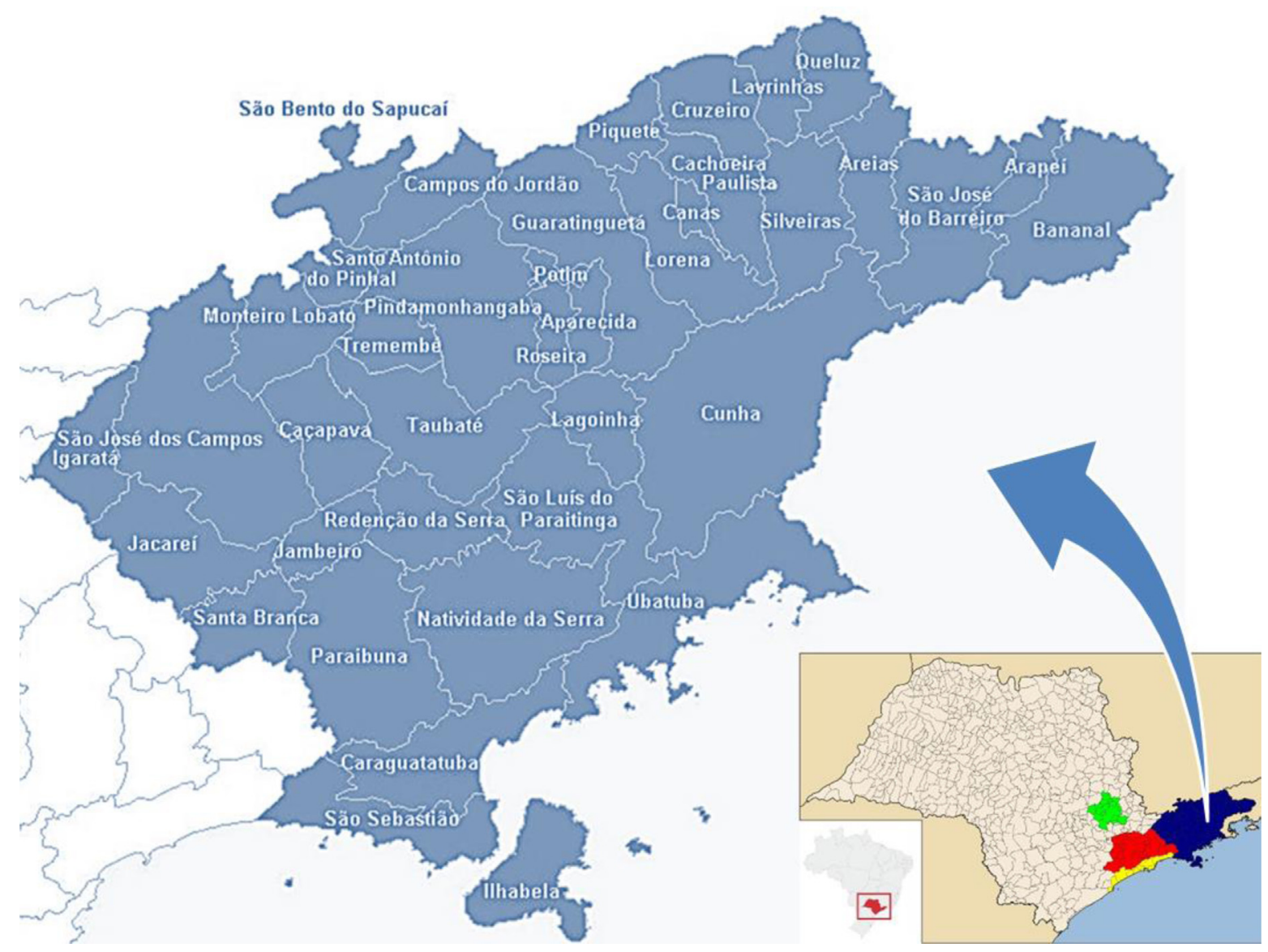

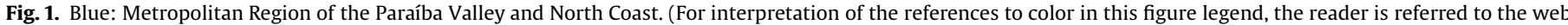
version of this article.)

Source: EMPLASA (2012) (adapted) 
of this industry received some guidance for its main environmental aspects, especially regarding water consumption, use of electricity, solid waste generation and greenhouse gas emissions.

\section{Materials and methods}

\subsection{Study place}

The study was developed at the headquarters of a parts and auto parts company in the automotive sector, located in the metropolitan region of the Paraíba Valley and North Coast (Fig. 1), State of São Paulo, Brazil.

This factory plant has eight thousand direct employees, with gross sales of, proximally, US\$772.2 million for the year 2012. It obtained the ISO 14001 series certification in the early 2000s after the introduction of an EMS by the company, which has a structure in the form of an environmental committee also implemented in all business units.

This study can also be directed to other plants of the company to improve the EMS model developed.

\subsection{Environmental committee}

There is no environmental department within the plant. The environmental management of the enterprise occurs by means of an environmental committee, composed of a team of six people from different areas and sectors of the company who defines the environmental management of water, energy, solid waste, greenhouse gas (GHG) emissions and the total area of the plant. The director of the company's quality is part of the environmental committee, currently the most senior employee who participates in the committee.

\subsection{LIFE certification}

LIFE Institute was legally conceived in 2009 through the efforts of the Fundação Grupo Boticário de Proteção à Natureza, Fundación AVINA, Posigraf (Publisher and Print Shop of Positivo Group), and the SPVS (Sociedade de Pesquisa em Vida Selvagem e Educação Ambiental) (LIFE, 2012e). In 2009 began development of LIFE certification, aiming to recognize enterprises that develop $A B C$ in proportion to their own size and environmental impacts caused by production processes, calculated from of VEIB (value estimated of impact on biodiversity).

The foundations of LIFE methodology were developed in Brazil in a process that involved 198 professionals and 96 organizations at public meetings, technical meetings and pilot audits. LIFE Certification is an international applicability instrument adaptable to any country. The adaptation work is carried out based on the methodology developed by LIFE Institute, with reference always the latest official versions approved by LIFE Institute and used in Brazil.

In 2013 has started the operation of certification system. Until 2015, three companies in Brazil obtained the certificate through independent evaluations conducted by Paraná Institute of Technology. The three companies received LIFE certification because develops actions for biodiversity conservation voluntarily.

The certification is valid for five years, and the recognized organization annually receives third party audits, which assess the ongoing projects and determine whether the organization retains or loses the certificate.

Public recognition of LIFE certification for conservation actions occurs by assigning a score to each type of project and managed model used by the company. Focusing on biodiversity conservation prioritizing the $A B C$, which considers international guidelines and priorities and the national scenarios. All $\mathrm{ABC}$ performed due to compliance with current legislation are not considered $A B C$ because are not voluntary.

However, to industry find out how many points need do in $A B C$, first, they need calculate the value estimated of impact on biodiversity (VEIB) which develop.

Calculation of VEIB considers two types of environmental aspects directly and indirectly related to biodiversity: the environmental aspects considered indirectly related to biodiversity are water consumption, electricity use, solid waste generation, and greenhouse gas emissions. The total area occupied by the enterprise is considered as an environmental aspect directly related to biodiversity due its occupation area in this biome.

Through these two types of environmental aspects, it is possible to obtain an environmental impact index, comparable between organizations and different plants of the same organization.

The Millennium Ecosystem Assessment report formed the basis for the choice of environmental aspects (LIFE, 2012e). According to the report, the main factors that influence the global biodiversity loss are habitat destruction, climate change, the introduction of invasive alien species, overexploitation of species and pollution (LIFE, 2013a,b). They chose the main economic activities that accelerate the rate extinction (Ricklefs, 2010).

For that reason, environmental aspects used to calculate the VEIB were selected from four benchmarks that enable the realization of calculations (LIFE, 2012a,b,c,d,e): (1) Relevance to the loss of global biodiversity; (2) Measurement of feasibility; (3) Availability of data; (4) Ability to obtain data for organizations of any size or sector.

\subsection{The VEIB and $A B C$ methodology}

For calculate the VEIB and the ABC, we used the publications developed by LIFE Institute:

- LIFE-BR-TG01-2.0 for VEIB;

- LIFE-BR-TG02-2.0 for ABC.

These publications give the steps required to perform the calculations. Calculations were made through spreadsheet Microsoft Excel, while the LifeKey, free and electronic tool, which will perform all of calculations through LIFE Institute website. These were the most recent LIFE publications available at the time of this study.

\subsection{VEIB-value estimated of impact on biodiversity}

Environmental aspects are fundamental items to calculate of VEIB. However, many analyzes of EMS can be performed while preparing for the calculation of VEIB. First, it should be calculated the quantity value $(\mathrm{QV})$ and the severity value (SV) of each environmental aspect.

QV indicates the quantity used of environmental aspects by industry, and SV indicates the severity of each environmental aspects. Below are all equations to calculate QV and SV:

\begin{tabular}{ll}
\hline For $\mathrm{QV}$ and SV waste generation: & \\
$1 . \mathrm{QVw}=\frac{\mathrm{WG}}{\mathrm{RVwaste}}$ & $2 . \mathrm{SVw}=\left(\frac{\mathrm{HW}}{\mathrm{WG}}\right)+0.001 \times\left(\frac{\mathrm{NHW}}{\mathrm{WG}}\right)$ \\
$\begin{array}{l}\text { For QV and SV ghg: } \\
\text { 3.QVghg }=\frac{\mathrm{GHG}}{\mathrm{RVghg}}\end{array}$ & $4 . \mathrm{SVghg}=\frac{\mathrm{GWP}}{\mathrm{GWPmax}}$ \\
$\begin{array}{l}\text { For QV and SV water consumption: } \\
5 . \mathrm{QVwC}=\frac{\mathrm{WC}}{\mathrm{RVwr}}\end{array}$ & $6 . \mathrm{SVwC}=$ InverseofHydricRegime \\
$\begin{array}{l}\text { For QV and SV energy consumption: } \\
\text { 7.VQe }=\frac{\mathrm{EC}}{\mathrm{RVghg}}\end{array}$ & $8 . \mathrm{SVe}=\frac{\mathrm{AW}}{\mathrm{AWmaximo}}$ \\
\hline
\end{tabular}


$W G$ = total waste generation by industry by year analyzing;

$\mathrm{RV} x=$ reference value for Brazilian industries to environmental aspect analyzing, according to Table A1 in Appendix A;

$\mathrm{HW}=$ total hazardous waste, according to Brazilian classification of solid waste NBR 10,004;

NHW = total waste not hazardous, according to Brazilian classification of solid waste NBR 10,004;

$\mathrm{GHG}=$ total GHG emissions by industry by year;

GWP-global warming potential = average GWP of GHG emitted by organization, weighted by their amounts (in CtO2e);

GWP $\max =$ according to Table A3 in Appendix A;

$\mathrm{WC}=$ total water consumption by industry by year analyzing;

Inverse of Hydric Regime= rate between the lowest water availability between the river basin districts of the country and the water availability in the river basin district where the organization is located, as shown in Table A4 in Appendix A;

$\mathrm{EC}=$ total energy consumption by industry by year analyzing;

$\mathrm{AW}=$ average weighted of potential impact of the energy matrices used by the organization;

AW maximum = value obtained from Table A2 (in Appendix A), which indicates the impacts of sources of energy impact.

Only determining the QV and the SV not allow compare the results, because they have different natures and units. Therefore, must make conversion to quantity index (QI) and severity index (SI) to each environmental aspect calculated, indirectly related with biodiversity.

For conversion of each environmental aspect in QI, should be applied following Eq. (9):

$\mathrm{QI} x=\left(1-\frac{1}{1+a x \times \mathrm{QV} x}\right) \times 1000$

$x$ : environmental aspect (energy, water, waste and ghg);

$a x$ : scale correction factor distribution of the indexes for each environmental aspect;

LIFE Institute defines a correction factor scale of indexes distribution for each one environmental aspect, as follows:

$(w)$ Waste : 5000; (g)Gases : 30,000;

(wr)Water : 3000; (e)Energy : 5000

These scale correction factors are explained in LIFE-BR-TG012.0-Portugues-for VEIB.

QI presents an asymptotic behavior, i.e., none organization can reach 1000 points on range corresponding in LIFE methodology. However, values close may exist.

SI associates QV information with SV from environmental impact to aspect considered. Thus, it combines a qualitative criterion to the severity of the environmental aspect evaluated. Also, SI comprehends results between zero and 1000. Eq. (10) shows the calculus to SI:

$\mathrm{SI} x=\mathrm{SV} x \times \mathrm{QI} x$

After calculated the QI and SI, is necessary sum all environmental aspects QI and SI to obtain TQI and TSI, respectively: total quantity index and total severity index.

$\mathrm{TQI}=$ QIwater + QIwastegeneration

+ QIenergyconsumption + QIghg

TSI $=$ SIwater + SIwastegeneration + SIenergyconsumption + SIghg

After conversion for indexes, it is possible compare all environmental aspects. Thus, the values of environmental aspects were converted to a dimensionless point scale, which also ranging from 0 to 1000 . The higher the value obtained by the organization, greater the impact on the environment generated by environmental aspect analyzed, therefore, the management of this environmental aspect need to be improved (Reale, 2014).

For environmental aspect occupation area, is calculated the occupation area value $(\mathrm{OAV})$ and, next, transform in the occupation area index (OAI). The Eq. (13) shows the OAV, and Eq. (14) shows the OAI:

$\mathrm{OAV}=\left(\frac{\text { Aorg }}{\text { Abio }}\right) \times\left(1-\frac{\text { Arem }}{\text { Abio }}\right)$

A org: area of industry;

A bio: original area of biome;

A rem: remaining area.

Original area and remaining area are defined through official reports, as shown in Table A5, in Appendix A.

OAI has a similar purpose to TQI and TSI that used to calculate the VEIB. This occurs to transform the occupation area aspect on the same scale of the previously calculated indices (TQI and TSI), enabling their sum and comparison. The factor "aoa" is intended to model the distribution. This value was obtained through tests the model for extreme values of occupation area.

$\mathrm{OAI}=\left(1-\frac{1}{1+(\mathrm{aOa} \times \mathrm{OAV})}\right) \times 1000$

aoa $=$ factor of scale of correction of distribution of occupation area of the OAI, equal to 200,000 .

Therefore, VEIB is calculated by Eq. (15)

$\mathrm{VEIB}=\frac{\mathrm{TQI}+\mathrm{TSI}+\mathrm{OAI}}{3}$

\subsubsection{Actions to biodiversity conservation $(A B C)$}

The minimum point value to be performed by industry in $A B C$ is calculated by Eq. (16)

$\mathrm{ABCminimum}=f(\mathrm{GS}) \times g(\mathrm{VEIB})$

The $f(\mathrm{GS})$ is standardized to American Dollars to the year of analyzing. The $g$ (VEIB) is the value found on results of Eq. (15). Thus, it is possible say that the higher the VEIB, biggest is the requirement in performance in $\mathrm{ABC}$.

Also, it is understood that largest companies can play a greater commitment to biodiversity when compared to smaller companies.

Then the functions $f(\mathrm{GS})$ and $g(\mathrm{VEIB})$ are given by:

$$
\begin{aligned}
& f(\mathrm{GS})=a \ln (b \mathrm{GS}+1)+1 \\
& a=3.1 \\
& b=4.94 \times 10^{-7} \\
& g(\mathrm{VEIB})=\left(\frac{c}{1,000-\mathrm{VEIB}}\right)+d \mathrm{VEIB} \\
& c=3.53 \times 10^{5} \\
& d=15
\end{aligned}
$$

The letters " $a$ ", " $b$ ", “c" and " $d$ " are constant determined by LIFE Institute, to represent the minimum score demanded in conservation actions. Then, the total score of biodiversity conservation projects that the company has already developed is calculated, i.e., the $A B C$ conducted.

If the $A B C$ minimum is not enough, the $A B C$ to conduct is calculated:

$\mathrm{ABC}$ to conduct $=\mathrm{ABCmin}-\mathrm{ABC}$ conducted 
The result of $A B C$ minimum indicates the value in scores that the organization should develop to mitigate, minimally, its environmental impacts on biodiversity. The ABC score can be achieved through the development of environmental projects. Then, the organization needs to develop conservation actions that fall into one or more groups $(G)$ of the strategic lines of conservation and/or sustainable use of biodiversity, defined by LIFE Institute methodology.

They are five groups, structured in a decreasing hierarchy of score. They represent the priority strategic lines to conservation and consider its potential to generate effective results. The five groups are:

G1-officially established protected areas;

G2-protected areas not officially established;

G3-taxa of interest for conservation;

G4-minimization of impacts on biodiversity;

G5-indirect actions in a comprehensive and strategic framework for biodiversity conservation.

The score of each group of aspects has the following order:

Highestscore $\rightarrow$ Lowerscore

$\mathrm{G} 1>\mathrm{G} 2>\mathrm{G} 3>\mathrm{G} 4>\mathrm{G} 5$

Within the five groups there are subdivisions according to the main theme of $A B C$ developed and can be divided into one of three themes: creation, planning or implementation. Each of these themes is given different scores, according to the following hierarchy: Development > Planning > Implementation.

The creation of protected areas guarantee the maintenance of the composition, structure and functioning of ecosystems. The planning and implementation of each action, in turn, reinforce the actions that were previously structured and therefore more likely to generate positive results and follow-up over time.

\subsection{Calculation of $A B C$ conducted}

LIFE-BR-TG02-2.0 document is meant to guide the procedures of calculations of the $\mathrm{ABC}$ conducted. Due to the high complexity of these calculations, they will not be demonstrated in this study. However, details can be read directly from LIFE Institute's website.

LIFE Institute describes and lists a number of preservationist and conservationist actions founded by the directive LIFE for biodiversity conservation: "Maintenance of the composition, structure and function of ecosystems". Thus, there is the appreciation of shares in conservation and/or sustainable use of biodiversity, enabling enterprises to be guided in their actions, which can be closer or easier to mitigate its impacts on environmental resources.

LIFE certification stimulates, valorizes and disseminates the $\mathrm{ABC}$ to allow:

- Immediate intervention in reversing the trend of the disappearance of biomes, ecosystems, and/or habitats and species;

- Correspondence with objective programs and international conventions;

- Calling for the conservation of natural priority areas;

- Calling for the priorities of species of interest for conservation;

- Strengthening of public policies for conservation.

It is emphasized that all actions, or the only action that the company develops, should be continued and improved throughout the duration of the certificate (five years). Annual monitoring audits exist to assess qualitatively and quantitatively the projects that occur until the last recertification audit, which occurs in the fifth certification year. Failure to comply during any audit monitoring may lead to suspension and, depending on the severity and measures proposed by the project, can result in the cancellation of the certificate.

\subsection{Data collection}

The environmental committee received the three questionnaires shown in Fig. 2. Two questionnaires are responsible for collecting data to calculate the VEIB, the $A B C$ minimum and the ABC conducted:

1) LIFE-BR-F01-Pre-Avaliacao-geral: VEIB and ABC minimum;

2) LIFE-BR-F02-Pre-Avaliacao-acoes: ABC conducted.

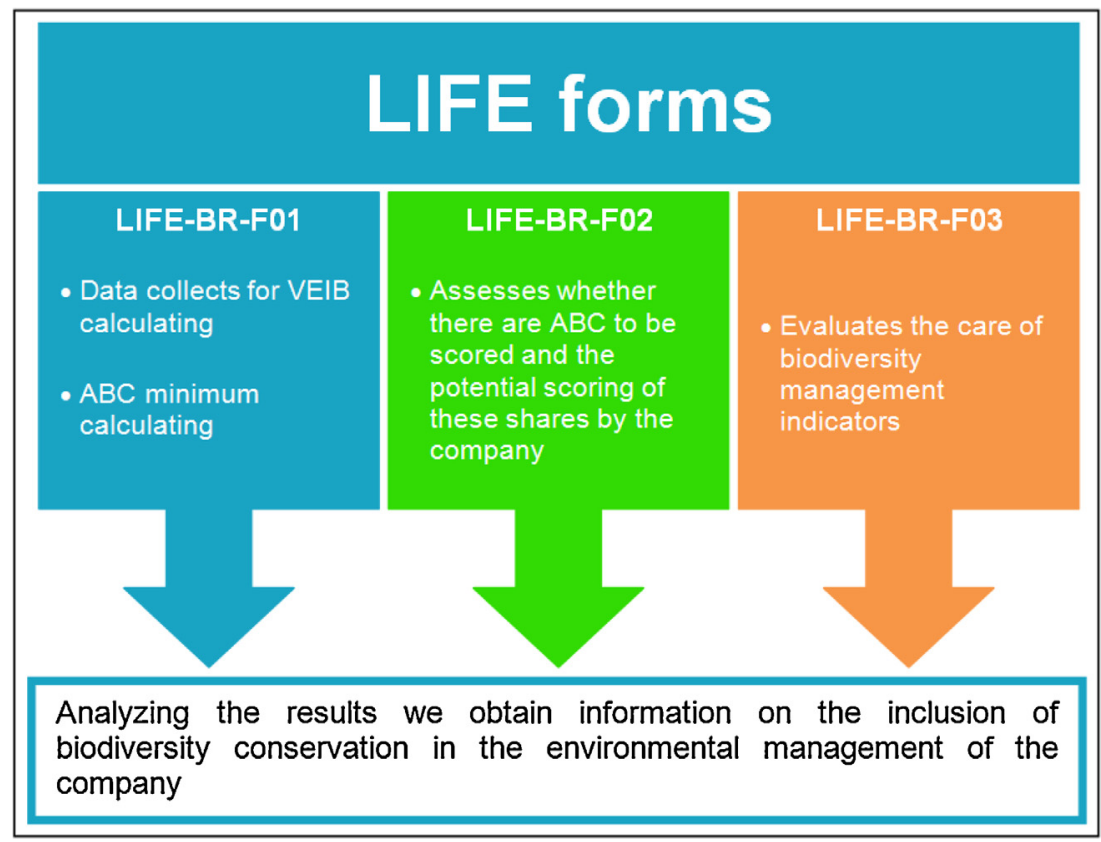

Fig. 2. LIFE questionnaires to making the diagnosis. 
Three technical visits were conducted by the project as part of the data collection procedures, including interviews with managers and explanations of the importance of filling out LIFE questionnaires.

Fig. 2 shows all questionnaires used to collect data to VEIB, ABC and LIFE indicators.

\section{Results and discussion}

\subsection{VEIB}

Table 1 shows the data collected from the questionnaire LIFEBR-F01-Pre-Avalicao-geral:

The data in Table 1 were applied in the equations at 1-8 for calculate all environmental aspects of QV and of QS. Then, it is necessary converted these results in QI and SI, using Eq. (9), for QI and Eq. (10), for SI. Results of all environmental aspects of QI are presented in Fig. 3, and all environmental aspects of SI are presented in Fig. 4:

While Fig. 3 only indicates the uses of environmental aspects by industry, Fig. 4 indicates the severity from each aspect.

The high SI energy occurs because in this factory, the sources energy is the hydroelectricity and the fossil fuels. Also, this organization does not have proposals for improvements in their use. Also, not have been submitted proposals to efficient uses of energy, as well as for alternative and renewable energy sources.

The great waste solid generation shown in Fig. 3 has low severity to biodiversity (Fig. 4). This because $80 \%$ of total volume residue generated in this industry is not contaminated or does not contain dangerous characteristics, being resold to other companies in the same group.

Although insignificant to the VEIB of industry, water and GHG have great potential to be minimized. But, the company has not presented programs intended to minimize the consumption of water, neither to reduce GHG emissions.

During the technical visits, the company showed no interest in discussing new practices about sustainable. However, it is emphasized the executive management's willingness to open its doors for this study. This indicates that a new approach is being born within the enterprise, because it never authorizes this type of approach for external members of a group of employees. This was the first external study case within this company.

To calculate the OAI, the area of this industry is 39.95 ha. This region is the Atlantic Forest Biome area.

Therefore, using Eqs. (14) and (15) to calculate OAV and OAI, respectively:

$$
\begin{aligned}
\text { VOA } & =\left(\frac{39.95 h a}{110,396,100 h a}\right) \times\left(1-\frac{24,563,132 \text { ha }}{110,396,100 h a}\right) \rightarrow \text { OAV } \\
& =2.813 \times 10^{-7}
\end{aligned}
$$

$$
\begin{aligned}
\mathrm{OAI} & =\left(1-\frac{1}{\left.1+200,000 \times 2.813 \times 10^{-7}\right)}\right) \times 1000 \rightarrow \mathrm{OAI} \\
& =53.26
\end{aligned}
$$

Thus, calculating the VEIB through Eq. (15)

$\mathrm{VEIB}=\frac{\mathrm{TQI}+\mathrm{TSI}+\mathrm{OAI}}{3}$

TQI and TSI are finding using Eqs. (11) and (12), respectively, therefore:

$\mathrm{VEIB}=\frac{539.57+166.83+53.26}{3}$

$\mathrm{VEIB}=253.22$

Therefore, during the calculation of VEIB, we can analyze which environmental aspects should improve their modes to minimize, or even prevent, impacts to the external and internal environment in the industry.

Opportunities to improve the management of all environmental aspects assessed were identified because there are no proposals to minimize any environmental aspects (water, energy, solid residue and GHG).

Mathematically, as a result of a conceptual matter that originated in the development of VEIB, Technical guide LIFE TG01-version 1.0 (LIFE, 2012a,b,c,d,e), there is no possibility for the company to reach the limit of 1000 points in the VEIB because it would represent an absolute and exclusive impact on biodiversity.

One of the main functions of VEIB is the direction of management actions to the environmental aspects of most significant impact. In this regard, the industry could revise its mode of production and the management of environmental aspects that have a high final score, always seeking the best tools and technologies available to minimize use, consumption and environmental emissions

\section{2. $A B C$ minimum}

After the VEIB calculation, the value of the $\mathrm{ABC}$ minimum being developed by the company can be obtained by multiplying the functions $\mathrm{f}(\mathrm{GS})$ by $\mathrm{g}(\mathrm{VEIB})$, i.e., using Eqs. (17) and (18)

$f(\mathrm{GS})=a \ln ((b \mathrm{GS})+1)+1$

The gross sales (GS) of industry in 2012 is US $\$ 772,200,772,2$ and the factor " $a$ " and factor " $b$ " are, respectively, 3.1, and $4.94 \times 10^{-7}$. Thus:

$\left.\left.f(\mathrm{GS})=3.1 \times \ln \left(\left(4.94 \times 10^{-7}\right) \times 772200772.2\right)+1\right)\right)+1$

$f(\mathrm{GS})=19.43$

And:

$g(\mathrm{VEIB})=\left(\frac{c}{1000-\mathrm{VEIB}}\right)+d \mathrm{VEIB}$

The factor " $c$ " and " $d$ " is, respectively, $3.53 \times 10^{5}$ and 15 , thus:

$g($ VEIB $)=\left(\frac{3.53 \times 10^{5}}{1,000-253.22}\right)+(15 \times 253.22)$

Table 1

Volume of each environmental aspect obtained from the questionnaire LIFE-BR-F01.

\begin{tabular}{lll}
\hline Environmental aspect (unit) & Data collected in industry & National reference value (2011) \\
\hline Waste generation (t/year) & 53192.39 & $150,422,658$ \\
GHG (tCO2e/year) & 32124.45 & $2,192,601,000$ \\
Water consumption ( $\mathrm{m}^{3} /$ year) & 404,785 & $38,221,632,000$ \\
Energy consumption (tep/year) & 4097115.89 & $246,636,000$ \\
\hline
\end{tabular}




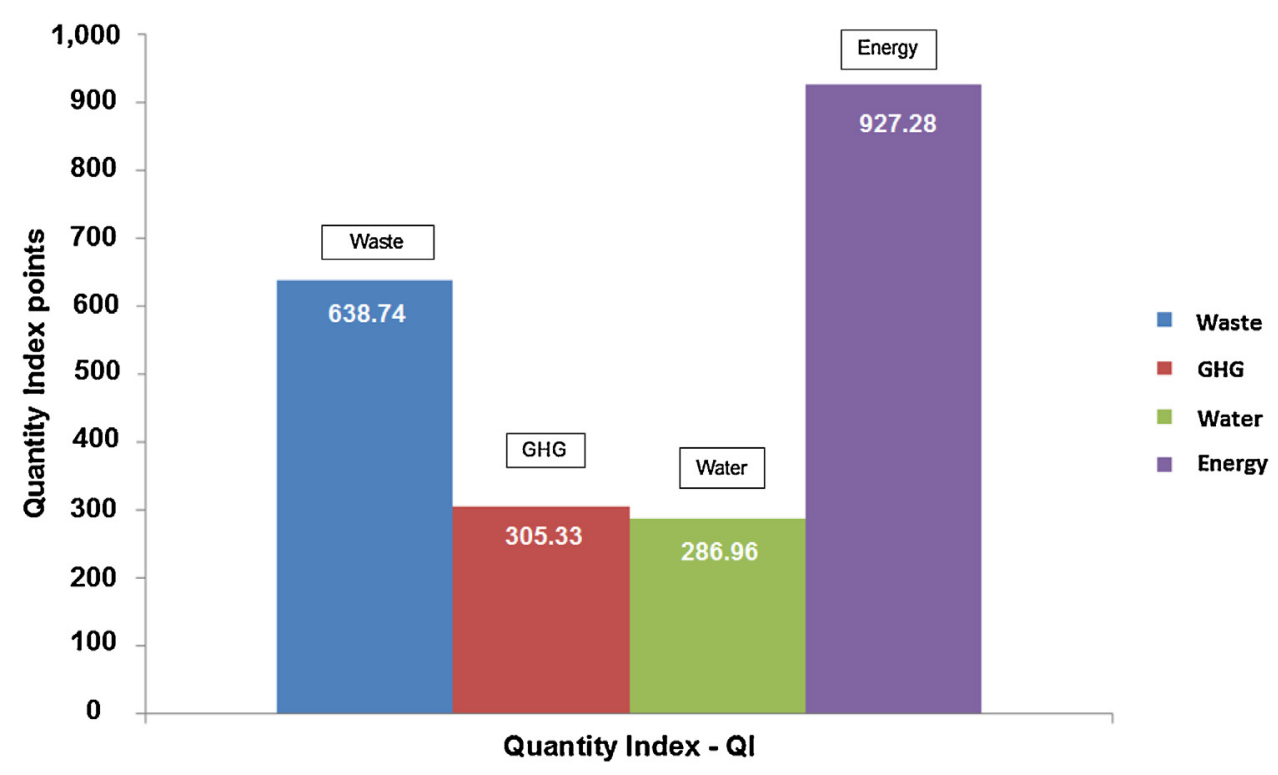

Fig. 3. Quantity index for each environmental aspect, assessed on a scale from zero to 1000 points.

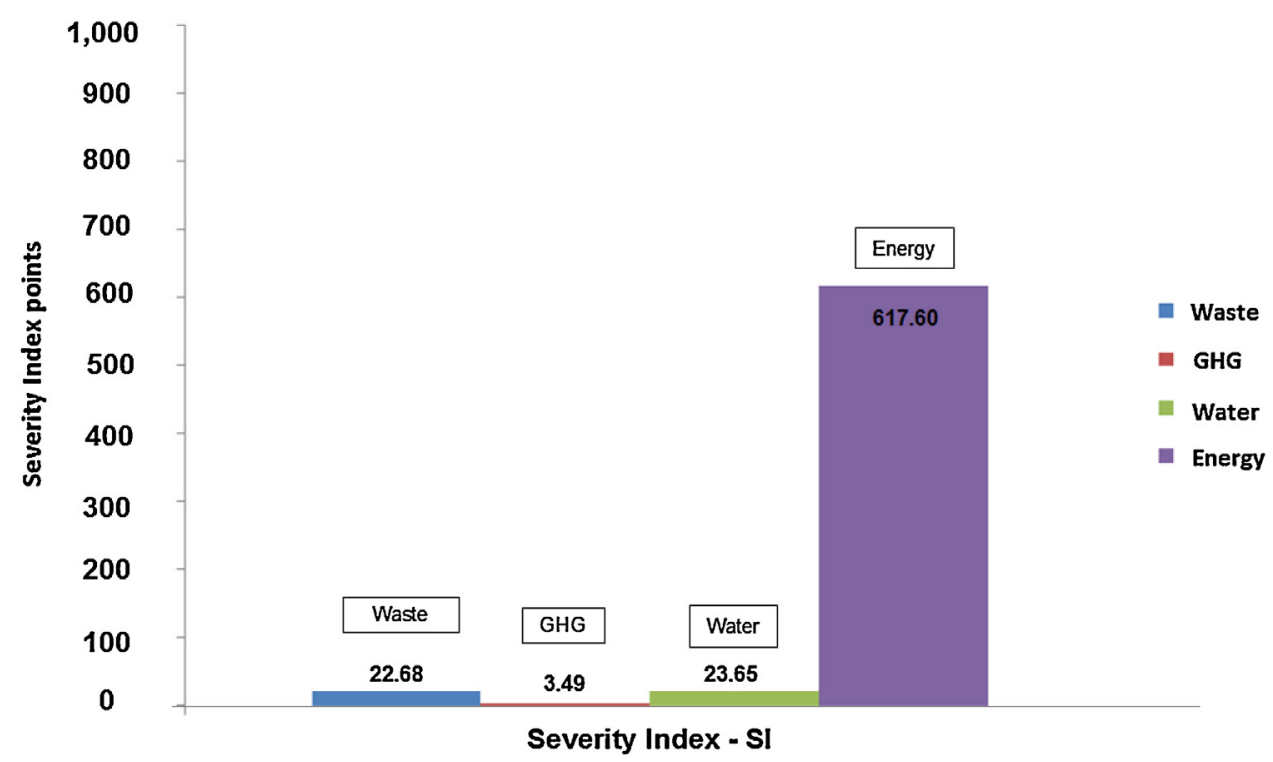

Fig. 4. Severity index for each environmental aspect, assessed on a scale from zero to 1000 points.

$g(\mathrm{VEIB})=4271$

Calculating the $\mathrm{ABC}$ minimum:

$\mathrm{ABCminimum}=f(\mathrm{GS}) \times g(\mathrm{VEIB})$

ACBmınimo $=(18.44) \times(4,271)$

\section{ACBmınimo $=78757.24$}

Then, according to the $A B C$ minimum calculation, the $A B C$ minimum has a value of 78757.24 points. Thus, this is the minimum score that a project should develop for which environmental impacts could be compensated with voluntary biodiversity conservation.
There is no maximum value for the $A B C$ minimum because there is no limitation on the actions to be performed and these practices are directly related to the company's environmental philosophy.

\section{3. $A B C$ conducted and $A B C$ to conduct}

In the questionnaire LIFE-BR-F02, the industry responded about its environmental volunteers projects, developed in this same plant. According the questionnaire, the industry only develops two environmental actions.

However, the response in LIFE-BR-F02 must comply with the Principle 5: Priority and complementarity between the environmental management and compensation of impacts to biodiversity. This principle provides:

"The organization shall respect the following hierarchy of management of negative impacts on biodiversity: first avoid generating impacts, minimize the unavoidable environmental 
impacts, recover damages caused by impacts performed, and then compensate those residual impacts." (LIFE, 2012a)

The two actions are: expansion of Sewer Treatment Plant (STP) and Water Treatment Plant (WTP); and monitoring of water quality of the Paraiba do Sul River.

\subsection{ABC not considered: expansion of STP/WTP}

Just expand the STP/WTP does not promote improvements in the company's EMS. This only meets legal requirements regarding the environmental licensing required for a future and possible expansion of this plant unit. This action it was not considered an ABC. Furthermore, is considered as opposed to ecological principles of environmental prevention and precaution, which should emphasize the imperative need to reduce the consumption of water resources.

The company could reuse water in its production processes or in toilets. This action has not been performed and there is no pretension of it being deployed, according the responses. In addition to bringing environmental gains to the resource economy, these environmental actions may generate savings to the business. Borsato (2012) showed that the environmental managers of companies, voluntary environmental management standards results in economic gains (public recognition and market gain), as well as technical and environmental benefits (reduction of pollution) and education (awareness).

The better use and management of sewage would be of great value to minimize the QI and SI of water. In the company circulates approximately eight thousand people daily. This number represents $10 \%$ of the municipality population of the company installation that does not have a sewer treatment plant.

For industrial production, water reuse projects were not presented with the argument water is not an essential item for the company's production. However, they noted that in the case of expansion of the productive sector and a possible company expansion, it would not be a limiting factor due to increased generation of effluents.

For this reason, the expansion accomplished was not considered an $A B C$ but as only one work that will serve to meet the current environmental legislation (reactive and not proactive attitude) to increase industrial production in the future, which is not dependent on the aspect of environmental water.

It is noteworthy that for this possible increase in industrial production, possible improvements that can be made in energy issues of the company have not been evaluated, as they will further increase the quantity and severity of energy and residue, which in turn, will increase the final VEIB.

If better management of the reform of STP/WTP had occurred that not only permitted the minimization of water consumption

Table 2

Types of conservation actions $(\mathrm{ABC})$ and their expected results.

\section{Types of ABC}

- Maintain, buy or donate land for conservation

- Implement mechanisms in areas of conservation (REDD, PSA, PSE, etc.)

- Implement fauna management actions and/or flora conservation

- Operationalize protected areas

- Conserve protected areas beyond legal requirements

- Connect fragments and/or mosaics created

- Monitor protected areas or equivalent

- Conduct studies, research and monitoring for conservation

- Strengthen policies and networks for biodiversity conservation

- Manage activities aimed at the sustainability of natural resources

- Conduct environmental education activities aimed at conservation

- Create, structure and make available databases for conservation

- Manage impacts on biodiversity

- Conserve actions ex-situ

- Execute the mapping and georeferencing of conservation areas

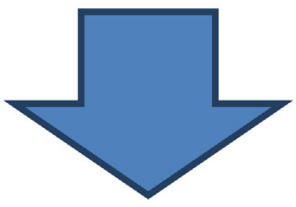

\section{Expected results}

- Preservation/conservation of natural areas

- Maintaining of the integrity of ecosystems (composition/structure/function)

- Generation of information for conservation

- Sensitivity to conservation 
but also reduced the emission of GHG, the generation of solid waste would provide energy minimization. Moreover, the monetary value applied to the reform of STP/WTP could be redistributed to other sectors of the enterprise.

\subsubsection{ABC considered: monitoring of water quality of the Paraiba do} Sul River

According to the technical guide LIFE-BR-TG02-2.0, the project belongs to group number 5 (G5), i.e., "indirect actions in comprehensive and strategic framework for biodiversity conservation", linked to theme number 3 (T3), i.e., "monitoring actions of indirect contributions to biodiversity conservation." After consult the guide we have:

$\mathrm{ABC}$ to conduct $=690$ points

Therefore, the required $\mathrm{ABC}$ to conduct for the company to perform is:

$\mathrm{ABC}$ to conduct $=\mathrm{ABC}$ minimum $-\mathrm{ABC}$ conducted

Thus: $A B C$ conducted $=78,757.24$ points -690

$A B C$ conducted $=78,067.24$ points

To obtaining certification, in the first year, the industry can perform $70 \%$ of $A B C$ minimum. The remaining $30 \%$ must be made within five years of validity of the certificate, provided that each stage of the missing score is announced. For the industry in question, it should achieve a score of $54,647.07$ points if it possesses interest in receiving LIFE certificate.

This score could be performed by $A B C$ within the enterprise itself, in partnership with companies, NGOs, and even spheres of municipal, state and federal governments, always focusing on internalizing the concepts of the importance of preserving biodiversity. Table 2 shows some possible ABC.

To demonstrate how this score significant is, it was choose the $A B C$ in group G1: Protected areas officially instituted and the theme 'creating protected area'. This was chosen because the G1 is the group of highest score on LIFE methodology.

Table 2 shows the types of conservation actions that enterprises can develop to increase their $\mathrm{ABC}$ scores.

Also, this choice occurred because the factory is located close to several protected areas, facilitating the $\mathrm{G} 1$ action by the possibility of developing the $\mathrm{ABC}$ in several different protected areas. This is an important region of Sao Paulo, Rio de Janeiro and Minas Gerais States, which contain four protected areas officially mentioned by Le Saout et al. (2013) as among the 10 most irreplaceable places in the world for the conservation and preservation of species of endangered vertebrates.

It was applied the guide LIFE-BR-F02-2.0 for know what was the size of protected area that this industry need to mitigate its score of $\mathrm{ABC}$ minimum.

The company could create, develop or adopt one or more areas whose sum is $\mathbf{5 7 4 9 . 5 3}$ ha, which is needed to achieve the $70 \%$ score of the $A B C$ to conduct in the zero year certification. That would be the size in protected areas necessary for the company neutralizes their environmental impacts. It is imperative that $30 \%$ of this area must be located in the same state and biome which the company is located. This information demonstrates in practice that LIFE certification can, as predicted by Borsato et al. (2014), promote

Table A1

Reference values to environmental aspects.

\begin{tabular}{lll}
\hline Environmental aspect & Reference value & Unit \\
\hline Waste generation & $150,422,688$ & $\mathrm{t} / \mathrm{year}$ \\
GHG & $2,192,601,000$ & $\mathrm{tCO}_{2} \mathrm{e} /$ year \\
Energy consumption & $246,636,000$ & toe/year \\
Water consumption & $38,221,632,000$ & $\mathrm{~m}^{3} /$ year \\
\hline
\end{tabular}

Source: LIFE-TG01-2.0-Português (2012).
Table A2

Sources of energy impact.

\begin{tabular}{ll}
\hline Energy source & Impact index \\
\hline Mineral coal & 86 \\
Oil and oil products & 79 \\
Hydroelectricity & 72 \\
Biofuels (biodiesel and oils) & 67 \\
Biofuels (alcohol) & 63 \\
Nuclear/fission & 60 \\
Natural gas & 57 \\
Biomass (firewood) & 53 \\
Biomass (residual) & 52 \\
Biogas & 43 \\
Geothermal & 40 \\
Thermal tides & 38 \\
Wind power & 24 \\
Solar & 19 \\
\hline Source: LIFE-TG01-2.0-Português (2012).
\end{tabular}

Table A3

GHG and their global warming potentials (GWP).

\begin{tabular}{|c|c|c|}
\hline Gas & Chemical formula & GWP \\
\hline Carbon dioxide & $\mathrm{CO}_{2}$ & 1 \\
\hline Methane & $\mathrm{CH}_{4}$ & 21 \\
\hline Nitrous oxide & $\mathrm{N}_{2} \mathrm{O}$ & 310 \\
\hline \multicolumn{3}{|l|}{ Hydrofluorocarbon (HFC) } \\
\hline HFC-23 & $\mathrm{CHF}_{3}$ & 11,700 \\
\hline HFC-32 & $\mathrm{CH}_{2} \mathrm{~F}_{3}$ & 650 \\
\hline HFC-41 & $\mathrm{CH}_{3} \mathrm{~F}$ & 150 \\
\hline HFC-43-10mee & $\mathrm{C}_{5} \mathrm{H}_{2} \mathrm{~F}_{10}$ & 1,300 \\
\hline HFC-125 & $\mathrm{C}_{2} \mathrm{HF}_{5}$ & 2,800 \\
\hline HFC-134 & $\mathrm{C}_{2} \mathrm{H}_{2} \mathrm{~F}_{4}\left(\mathrm{CHF}_{2} \mathrm{CHF}_{2}\right)$ & 1,000 \\
\hline HFC-134th & $\mathrm{C}_{2} \mathrm{H}_{2} \mathrm{~F}_{4}\left(\mathrm{CH}_{2} \mathrm{FCF}_{3}\right)$ & 1,300 \\
\hline HFC-143 & $\mathrm{C}_{2} \mathrm{H}_{3} \mathrm{~F}_{3}\left(\mathrm{CHF}_{2} \mathrm{CH}_{2} \mathrm{~F}\right)$ & 300 \\
\hline HFC-143rd & $\mathrm{C}_{2} \mathrm{H}_{3} \mathrm{~F}_{3}\left(\mathrm{CF}_{3} \mathrm{CH}_{3}\right)$ & 3,800 \\
\hline HFC-152nd & $\mathrm{C}_{2} \mathrm{H}_{4} \mathrm{~F}_{2}\left(\mathrm{CH}_{3} \mathrm{CHF}_{2}\right)$ & 140 \\
\hline HFC-227ea & $\mathrm{C}_{3} \mathrm{HF}_{7}$ & 2,900 \\
\hline HFC-236fa & $\mathrm{C}_{3} \mathrm{H}_{2} \mathrm{~F}_{6}$ & 6,300 \\
\hline HFC-245ca & $\mathrm{C}_{3} \mathrm{H}_{3} \mathrm{~F}_{5}$ & 560 \\
\hline \multicolumn{3}{|l|}{ Hidrofluoresteres (HFE) } \\
\hline HFE-7100 & $\mathrm{C}_{4} \mathrm{~F}_{9} \mathrm{OCH}_{3}$ & 500 \\
\hline HFE-7200 & $\mathrm{C}_{4} \mathrm{~F}_{9} \mathrm{OC}_{2} \mathrm{H}_{5}$ & 100 \\
\hline \multicolumn{3}{|l|}{ Perfluorocarbons (PFCs) } \\
\hline Tetrafluoromethane & $\mathrm{CF}_{4}$ & 6,500 \\
\hline Hexafluoroethane & $\mathrm{C}_{2} \mathrm{~F}_{6}$ & 9,200 \\
\hline Perfluoropropane & $\mathrm{C}_{3} \mathrm{~F}_{8}$ & 7,000 \\
\hline Perfluorooctane & $\mathrm{C}_{4} \mathrm{~F}_{10}$ & 7,000 \\
\hline Perfluoro cyclobutane & $\mathrm{c}-\mathrm{C}_{4} \mathrm{~F}_{8}$ & 8,700 \\
\hline Perfluoropentane & $\mathrm{C}_{5} \mathrm{~F}_{12}$ & 7,500 \\
\hline Perfluoro hexane & $\mathrm{C}_{6} \mathrm{~F}_{14}$ & 7,400 \\
\hline Sulfur hexafluoride & $\mathrm{SF}_{6}$ & 23,900 \\
\hline
\end{tabular}

Source: LIFE-TG01-2.0-Português (2012)/ISO 14064:2007-Annex C.

gains in quantity and quality of $\mathrm{ABC}$ held by companies, differentiating the international market.

LIFE Institute proposal is to encourage companies to better exploit the environmental aspects they use. For this reason, the companies should develop several different environmental actions in several groups $(G)$ with lasting characteristics and high quality, always aiming to conserve biodiversity.

Accordingly, the area of 5749.53 ha could be lower if the company developing several other ABC actions, addressing G3, G4 and $\mathrm{G} 5$ as presented in the technical guide LIFE-BR-TG02. The area calculated would decrease further if the enterprise carried out improvements in the management of environmental aspects, which would minimize the VEIB and hence the ABC. 
Table A4

Inverse of the Hydrographic Region.

\begin{tabular}{ll}
\hline Hydrographic Region & Inverse of Hydric Regime \\
\hline Amazon & 0.001233931768 \\
Paraná & 0.015711325967 \\
Tocantins-Araguaia & 0.016706443914 \\
San Francisco & 0.048250265111 \\
Atlantic Southeast b & 0.082055906222 \\
Paraguay 0.116368286445 & 0.116368286445 \\
South Atlantic & 0.140649149923 \\
Uruguay & 0.161061946903 \\
Parnaiba & 0.240105540897 \\
Western Northeast Atlantic & 0.284375000000 \\
East Atlantic & 0.298360655738 \\
Eastern northeast atlantic & \\
\hline
\end{tabular}

Source: LIFE-TG01-2.0-Português (2012)/Agência Nacional de Águas - Conjuntura dos Recursos Hídricos no Brasil (2011).

a Eastern Northeast Atlantic is the water area of less water.

b Water area of this industry.

\section{Table A5}

Data Table for calculating the areas of Occupation Area Index (OAI).

\begin{tabular}{lll}
\hline Biome & Original area (ha) & Remaining area (ha) \\
\hline Amazon & $419,694,300$ & $354,626,516$ \\
Cerrado & $203,852,041$ & $104,290,704$ \\
Caatinga & $84,445,300$ & $44,111,700$ \\
Athlantic forest & $110,396,100$ & $24,563,132$ \\
Pantanal & $15,131,300$ & $12,580,163$ \\
Pampa & $17,800,000$ & $6,413,340$ \\
\hline
\end{tabular}

Source: LIFE-TG01-2.0-Português (2012).

The EMS of an industry cannot be restricted only to the current environmental legislation and mandatory laws. The environmental management of an enterprise should predominantly look for sustainable development. This increases the importance of the company to society and its market value.

The technical visits showed that the environmental committee format, although apparently functional and optimized, is decentralized do not having neither one environmental office. This indicates that there exists some distance between the top positions of the factory and the other sectors of the company evaluated for engagement with a sustainable theme. This proves once again that large industries have boards of directors not committed to sustainable development (Kiron et al., 2015).

However, the permission from the management of the company for the development of this study indicates the beginning of a new attitude regarding the environmental policy of the enterprise.

\subsection{Concluding remarks}

Rossi (2008) shows that firms in the Corporate Sustainability Index (ISE) have a market value between $10 \%$ and 19\% higher than the control group, who did not participate in the same wallet stock group.

The industry discussed here participated in the first three years of this select portfolio: 2005-2007. They did not say the reason for the wallet exit and demonstrated no interest in returning or if there was any difficulty in reaching the level required by the evaluators of the ISE. The company did not develop a sustainability report and did not justify why, it being the most important industry of its actuation area and of Latin America.

Any investments in the clean development mechanism and reducing emissions from deforestation and forest degradation, among other similar environmental projects, and any reductions of the VEIB and improvements of the score in terms of ABC conducted may enable interesting economic gains, in addition to strengthening the conditions for the company's reintegration into the ISE portfolio.

The high consumption of fossil fuels, due to logistic models of the receipt of raw materials and the flow of production, could be rethought with the introduction of the use of renewable fuels in many of its vehicles and those of outsourced partners and the encouragement of employees to go to work using a bicycle as their mode of transportation, taking advantage of the small size of the municipality where the company is located together with the benefit of the local geography being flat.

During data collection the existence of a pattern that has been described in the literature as "business as usual" can be seen, i.e., there are no major changes in investments for the green or environmental sector (Ferguson, 2015). Kiron et al. (2015) showed that the boards of large enterprises are seen as not committed to sustainable development.

Thus, if the management board is not engaged with the sustainable practices in the company, the technical team, which is subordinate, can hardly accomplish works of improvements identified by external agents. However, the fact that the management has contributed to this study indicates that a new position on the environmental policy of the enterprise is being born.

\section{Conclusion}

This study revealed that through the use of the LIFE methodology, it is possible to diagnose the effectiveness of an EMS, highlighting potential areas of improvements for management, including the minimization of expenses and optimization of investments and reforms. This is very important, especially when the EMS also values the efficiency of processes, which does not always culminate in the truly effective management of resources.

LIFE Certification can do the EMS incorporate the ABC, increasing efficiency enterprise management. Thus, this industry could apply for the certification after completing the document "LIFE Certification Standards" (LIFE-BR-CS-2.0, 2012), which presents the eight principles of certification aimed at incorporating biodiversity into environmental management business practices and is aligned with the objectives of the CBD: conservation of biodiversity, sustainable use of natural resources and fair and equitable sharing of environmental benefits.

The continuous improvement should receive greater attention because some areas of the enterprise are missing in this respect, such as the energy issue, or are receiving inappropriate investments, such as the renovation and expansion of the STP/WTP.

The industry has no environmental commitments to biodiversity conservation and does not have an understanding of the importance of preserving natural ecosystems nor its economic relationship with the conservation and preservation of biodiversity. However, there are several possibilities to adoption in its geographic region, facilitated by many important protected areas, close to the company.

This indicates that, if other companies in the Paraíba Valley region introduce this management model, as well as several other companies in their respective regions, the pro-biodiversity concepts to enterprise management will be incorporated, thus enabling intensifying of conservation actions in the protected areas in these regions.

\section{Acknowledgments}

The Coordenação de Aperfeiçoamento de Pessoal de Nível Superior (CAPES) by scholarship granted. To empoyees of industry which allowed this research. To Alan Eduardo de Barros for his great help to review of this article before submission. The editor in chief Martin Beniston and Reviewer 1 by contributions and review. 


\section{Appendix A.}

Table A1-A5 .

\section{References}

Borsato, R., 2012. Governança ambiental e as certificações: participação e influência do movimento ambientalista nos instrumentos privados de gestão. UFPR (Universidade Federal do Paraná) PhD dissertation.

Borsato, R., Mendes Filho, J.T., Milano, M.S., Salzmann, A.M., Brasil, B., Alexandre, M. A., Nunes, M.L.S., Borges, C., Posonski, M., 2014. Biodiversity accountability in Brazil: the role of LIFE (R) certification, Michael Jones. (Org.). Accounting for Biodiversity. 1st ed. Routledge, Abingdon and New York, pp. 172-188.

Bulhões, B.M., 2012. Biodiversidade e Indústria: informações para uma gestão responsável. Confederação Nacional da Indústria (CNI), Brasília.

Chapin, I.F.S., Zavaleta, E.S., Eviner, V.T., Naylor, R.L., Vitousek, P.M., Reynolds, H.L., Hooper, D.U., Lavorel, S., Sala, O.E., Hobbie, S.E., Mack, M.C., Díaz, S., 2000. Consequences of changing biodiversity. Nature [Internet] 405 (6783), 234-242. doi:http://dx.doi.org/10.1038/35012241 Available from: http://www.nature. com/nature/journal/v405/n6783/full/405234a0.html, (accessed 14.01.15.).

EMPLASA Secretaria de Desenvolvimento Metropolitano, 2012. Região Metropolitana do Vale do Paraíba e Litoral Norte. Imprensa Oficial, São Paulo.

Ferguson, P., 2015. The Green economy agenda: business as usual or transformational discourse? Environmen. Politics 24 (1), 17-37. doi:http://dx. doi.org/10.1080/09644016.2014.919748 (accessed 17.07.15.).

LIFE, 2012a. Padrões de Certificação LIFE: Princípios e Critérios da certificação LIFE. Dezembro de2012. Available from: http://institutolife.org/wp-content/uploads/ 2013/06/LIFE-BR-CS-2.0-Portugues.pdf, (accessed 10.01.13.).

LIFE, 2012b. LIFE-BR-TG01-2.0-Português. Atualização: 05/12/2012-Aplicabilidade: Brasil GUIA TÉCNICO LIFE-02. Definição de desempenho mínimo em Ações de Conservação da Biodiversidade-Abordagem Quantitativa da Certificação LIFEVersão Oficial-2.0; pg40. Available from: http://institutolife.org/wp-content/ uploads/2013/06/LIFE-BR-TG01-2.0-Portugues.pdf, (accessed 11.01.13.).

LIFE, 2012c. LIFE-BR-TG02-2.0-Português. Atualização: 20/12/2012-Aplicabilidade: Brasil GUIA TÉCNICO LIFE-02. Avaliação do Desempenho em Ações de Conservação da Biodiversidade - Versão Oficial - 2.0; pg84. Available from: http://institutolife.org/wp-content/uploads/2013/06/LIFE-BR-TG02-2-0Portugues.pdf, (accessed 11.01.13.).

LIFE, 2012d. Panorama de Certificação LIFE. Curitiba: Editora Posigraf.
LIFE, 2012e. RELATÓRIO-01-Histórico de Desenvolvimento dos Padrões LIFE e da Metodologia de Certificação LIFE. Curitiba: Editora Posigraf.

LIFE, 2013a. Cadernos Técnicos. Vol. I. Energia e Biodiversidade. Available from: http://institutolife.org/wp-content/uploads/2013/11/

CadernosTecnicos_Energia_Biodiversidade.pdf, (accessed 14.12.13.).

LIFE, 2013b. Cadernos Técnicos. Vol. II. Aspectos Legais. Available from: http:// institutolife.org/wp-content/uploads/2013/11/

Sumario_exec_Aspectos_Legais_site_FINAL.pdf, (accessed 14.12.13.).

Kiron, D., Kruschwitz, N., Haanaes, K., Reeves, M., Sonja-Katrin, F.K., Kell, G., 2015. Joining Forces: Collaboration And Leadership For Sustainability: Collaboration And Leadership For Sustainability. MIT Sloan Management Review, Massachusetts Available from: http://sloanreview.mit.edu/projects/joiningforces/, (accessed 20.01.12.).

Marques, H.C.F., 2000. Desenvolvimento Sustentável: proposta efetiva para o equacionamento da crise socioambiental ou um novo dispositivo de controle ideológico para a questão ambiental? Master's Thesis in Environmental Sciences. Centro de Estudos Ambientais da Universidade Estadual Paulista, Rio Claro.

Ricklefs, R.E., 2010. A Economia da Natureza, 6 ed. Editora Guanabara, Rio de Janeiro.

Le Saout, S., Hoffmann, M., Shi, Y., Hughes, A., Bernard, C., Brooks, T.M., Bertzky, B., Butchart, S.H.M., Stuart, S.N., Badman, T., Rodrigues, A.S.L., 2013. Science 342 (6160), 803-805. doi:http://dx.doi.org/10.1126/science.1239268.

Reale, R., 2014. A certificação LIFE como ferramenta solidária ao Sistema de Gestão Ambiental-Um estudo de caso. 99 f. Thesis (Specialization)-Curso de Especialização em Gerenciamento Ambiental (CEGEA). Departamento de Solos, ESALQ/USP, Piracicaba.

Rossi, J.L., 2008. What is the Value of Corporate Social Responsibility? An Answer from Brazilian Sustainability Index. Insper/IBMEC, São Paulo.

Sukhdev, P., Wittmer, H., Schröter-Schlaack, C., Nesshöver, C., Bishop, J., Brink ten, P., Gundimeda, H., Kumar, P., Simmons, B., Neuville, A., 2010. A Economia dos Ecossistemas e da Biodiversidade: Integrando a Economia da Natureza Uma síntese da abordagem, conclusões e recomendações do TEEB 2010. PNUMA Publication.

Tuffani, M., 2010. Lições de uma catástrofe. UNESP Ciência: Ponto Crítico, São Paulo, v. 13, p. 50, October. Mensal. Available from: http://www.unesp.br/aci/revista/ ed13/ponto-critico. (accessed 2015.). Ago 15.

Zolin, C.A., Folegatti, M.V., Mingoti, R., Paulino, J., Sánchez-Román, R.M., González, A. M.O., 2014. The first Brazilian municipal initiative of payments for environmental services and its potential for soil conservation. Agric. Water Manag. 137, 75-83. 